MLADEN M. JAKOVLJEVIĆ 1

UNIVERSITY OF PRIŠTINA IN KOSOVSKA MITROVICA

FACULTY OF PHILOSOPHY

DEPARTMENT OF ENGLISH LANGUAGE AND LITERATURE

\title{
TITUS GROAN'S JOURNEY: FROM GORMENGHAST TO THE CITY
}

\begin{abstract}
The protagonist's passage from the world of Gormenghast in Mervyn Peake's Titus Groan and Gormenghast, the first two volumes of the story, to the futuristic world of the City in the third volume, Titus Alone, is often seen as a break between the two worlds. This unexpected passage from one world to another also brings an unexpected switch to science fiction. Both these changes, the passage to another, radically different world and a shift to science fiction, are not so abrupt or radical as they may seem on the surface.

Placing the Gothic and science fiction features into the spotlight, while not denying the existence and importance of others, can show how the reality in the trilogy is shaped, how its two worlds are connected into a whole, and how they give one another shape in the overall picture of Gormenghast. Together, they can add to the illumination of the anomaly of Mervyn Peake's story of Gormenghast.
\end{abstract}

KeYWORDS: Mervyn Peake; Gormenghast; science fiction; Gothic fiction; fantasy.

$1 \quad$ mladen.jakovljevic@pr.ac.rs

The paper is the result of research conducted within project no. OI 178019 Translation in the System of Comparative Studies of National and Foreign Literatures and Cultures, funded by the Ministry of Education, Science and Technological Development of the Republic of Serbia.

This paper was submitted on September $9^{\text {th }}, 2020$ and accepted for publication at the meeting of the Editorial Board held on September $25^{\text {th }}, 2020$. 


\section{A VISIONARY ANOMALY}

Perhaps the best way to describe Mervyn Peake's Gormenghast trilogy, and his artistic work in general, is to adopt the term given by G. Peter Winnington who rightfully called it "anomalous" (2006, p. 2). The anomaly of Gormenghast is also among the main reasons why it has not gained wider recognition. The number of studies and papers about this work of literature grows by the day, slowly but steadily, and an adaptation of the Gormenghast series heading to TV screens, as a project by Neil Gaiman ${ }^{2}$, will undoubtedly draw additional attention of both readers and critics. While observations such as those that Peake is "almost entirely neglected by critics" (Winnington, 2006, p. 2) and that his "trilogy has attracted little academic recognition" (Binns, 1979, p. 21) will by all means soon belong to the past, Winnington's remark that Peake's work is "anomalous" will lose nothing of its power to describe its uniqueness, singularity, and distinctiveness.

Gormenghast is an odd work of literature that defies classification. Having no identifiable obvious precursors or followers it evades attempts to place it within a specific literary model.

As noted by Ronald Binns,

It belongs to no obvious tradition, lacks an ordered structure, is occasionally careless in detail, and breaks in two after the second volume, at the point where Titus Groan abandons Gormenghast for a picaresque journey through a quite different, more futuristic world. (Binns, 1979, p. 2)

This paragraph in a way briefly explains some reasons why it has taken so long for Peake's Gormenghast trilogy to gain wider recognition and awaken more interest among scholars. Owing to the changes in interests and focus, what used to be regarded as peculiarities, which marked it as significantly different from other works of fiction denoted as fantasy, can now be foregrounded as its unique features that make it not only a visionary piece of literary fantasy but also a work that was well ahead of its time.

As Binns insightfully noticed,

Gormenghast conjured up an ancient, feudal world, and evil contained itself in the single figure of Steerpike. By contrast, in an

2 Peake's Gormenghast series was previously adapted to a TV series by BBC in 2000. 
unidentified world of Titus Alone we get a vision of the future, more science fiction than Gothic romance, more urban and contemporary than the temporally and geographically remote society of Gormenghast. (Binns, 1979, p. 31)

Gormenghast now fits more comfortably among works of fiction written more recently, with its mixture of genres and its range of narrative strategies, those borrowed from the earlier times, but also those that announced tendencies that were yet to become more prominent. For example, it reaches back to Gothic novels with its medieval aura and abundance of recognizable Gothic tropes, and to modernism with the Bildungsroman themes of development of the protagonist Titus, and with its cinematic features and interior monologues, as for example in "Reveries" in Titus Groan. It also reaches forth to postmodernism with its multiplicity of genres, and its fragmented narrative in Titus Alone.

It is Titus Alone that is often seen as peculiarly anomalous, particularly when compared with the first two volumes. Its anomaly, however, need not be seen as a break, but as a step forward.

Tanya Gardiner-Scott analysed Titus Alone in its printed and prepublication forms and concluded that not only was the novel "carefully planned years in advance" but that it was conceived by Peake "more carefully than he is given credit for in the printed texts" and that this volume actually represents "a new stage of his artistic development" (Gardiner-Scott, 1989, pp. 70, 82). As pointed out by Brian McHale (1992), epistemologically oriented fiction is preoccupied with the questions about what is there to know about the world, who knows it and how reliably, whereas ontologically oriented fiction, like science fiction and postmodernism, is preoccupied with the questions about the nature of the world, how it is constituted, as well as with the relationship between different worlds. The protagonist's passage from Gormenghast to the City marks this "new stage of artistic development" that also brings about a shift from epistemological to ontological dominant.

\section{THE FUZZY SET(S) OF GORMENGHAST}

The absence of "obvious tradition" in Gormenghast, of course, does not mean that it does not contain any traditions at all. In fact, it contains a number of them, a lot of them actually, all fused into a 
whole. The variety of tropes that Gormenghast encompasses make it an eclectic piece of writing rooted in a complex mixture of genres whose boundaries within the trilogy can be said to "shade off imperceptibly", to borrow Brian Attebery's formulation as applied to a "fuzzy set" of fantasy defined "not by boundaries but by a center" (Attebery, 2004, pp. 304-305). And yet, although Gormenghast is considered to be a fantasy series, it is difficult to make easy comparisons and find direct relations with other works of fantasy. As a result, it is difficult to comfortably and convincingly place it within any of the individual sets, no matter how fuzzy they may be.

Perhaps a way to deal with this should be as anomalous as the work in question. One possible solution would be to dispense with placing Gormenghast into any specific sets other than its own, with its own multiplicity of centres, or sets it comprises. Another solution would be to allow it to unfold over and be part of several sets simultaneously, while dropping the insistence that the work as a whole or its greater part should occupy strictly or mostly one of them. Scholars have identified a number of centres in it, including those of fantasy, science fiction, Gothic fiction, tragedy, Elizabethan drama, Bildungsroman, postmodern novel, postcolonial fiction, satire, allegory, and medieval mystery plays. Additionally, the influences of Milton's, Carrol's, Dickens's, and Sterne's works are often noted, including the parallels between Steerpike's rise and that of Satan, similarities with Alice in Wonderland, Dickensian grotesqueness of the characters' names, and Titus's absence from much of the first part of the trilogy due to which Tristram Shandy is often recognized as the model for the protagonist (Binns, 1979, p. 24; Gardiner-Scott, 1988, p. 13; Hindle, 1996, p. 9; Mendlesohn, 2013, p. 69; Mills, 2005, pp. 57-58; Redpath, 1989, p. 68; Winnington, 2006, p. 180).

Although encompassing all of the above Gormenghast as a whole is unlike any of them specifically. For this reason, it can and should be a fuzzy set on its own, consisting of a number of other sets none of which should be given the all-time, universal priority. Instead, Gormenghast should be allowed to stay rooted and comfortably rest in many of them. Putting one or several such centres into the spotlight does not mean that these are given precedence or that others are less relevant or less important. Instead, the analysis focused on one or a couple of them can shed more light, from different angles, not only on that or those particular centres, but on the entire work as well. 
The multitude of centres reflects on the disordered and fragmented structure of Gormenghast. It is often noted that the trilogy breaks in two with Titus Alone, but the continuity may be found in the connections and relations between the details and the wholethose that exist within each of the two worlds, but also those between them-as well as in the relations between two fuzzy centres that the story encompasses: Gothic fiction and science fiction.

This combination of centres, however, is not an arbitrary or unusual mix. Gothic fiction and science fiction are closely related since the latter is firmly rooted in the former. As noticed by Brian Aldiss (1973, p. 18) "[s]cience fiction was born from the Gothic mode, is hardly free of it now. Nor is the distance between the two modes great."

\section{(NOT SUCH) A RADICAL BREAK}

Titus Alone is often thought to stand apart from the relatively rounded up story of the first two volumes. Most obviously, in Titus Alone, the shortest of the three novels, the protagonist, displaced from the realm of the pseudo-medieval world of Gormenghast, has found himself in a futuristic, industrial world whose architecture, industry, and advanced technology radically differ from that of Gormenghast.

There are differences between these two worlds, of course, but there are numerous similarities as well. In terms of loneliness, alienation, and grotesqueness the characters in Titus Alone easily match those in and around the castle. They are all equally incapable of communicating openly while on their unsuccessful quest for love and fulfilment. ${ }^{3}$ There is, however, something that reveals an even deeper connection between the parts and the whole.

In "The Artist's World" Peake highlighted the importance of seeing, of how he himself watches and sees things. His approach reveals how he achieved the immense depth and rich texture of his fictional world. This approach can be described as organic interconnectedness of everything on both micro- and macro- planes. While he was thinking about the title of the show "As I See It" and could not think of anything significant, for a while he "watched a bluebottle rubbing its wings together on the window pane and flex-

3 This as a subject deserves a separate analysis. 
ing its thread-like legs" and a ray of sunlight turned it into a "crumb of burning indigo." As he went on staring at the window, "beyond the fly and through the glass," he realized how everything, "the endless kaleidoscope of coloured shapes and patterns that swam across the vision" was interconnected (Peake, 2011a, pp. 5-6).

This interconnectedness is stronger in the first two volumes, in their endless kaleidoscope of Gormenghast in which Peake constantly shifts the focus from the fly, i.e. the meticulous description of the details within and around Castle Gormenghast, to the landscape beyond the pane, i.e. the world of Gormenghast as a whole.

In the first two volumes the puzzle of the static world of Gormenghast slowly unfolds before the reader, from its "boarded floor [...] white with dust" which was "so assiduously kept from the carvings" (Peake, 2011b, TG ${ }^{4}$ chap. $1^{5}$ ), or the napkins that "were folded into the shapes of peacocks and were perched decoratively on the two plates" (Peake, 2011b, TG chap. $9^{6}$ ), or "small thumb-marks on the margin of the page" that are "as important to [Steerpike] as the poems or the picture", or "the miniature and fluted precipice of hard, white discoloured flesh" of the pear in which "Fuchsia's teeth had left their parallel grooves" (Peake, 2011b, TG chap. 237), or the plaster "cracked into a network of intricate fissures varying in depth and resembling a bird's-eye view, or map of some fabulous delta" (Peake, 2011b, TG chap. $5^{8}$ ), to the wider perspective of irregular roofs over which "throughout the seasons" fall "the shadows of time-eaten buttresses, of broken and lofty turrets, and, most enormous of all, the shadow of the Tower of Flints" (Peake, 2011b, TG chap. 1), and eventually to its vast landscape viewed from the slopes of Gormenghast mountain enshrouded in the mist that spreads from horizon to horizon, "supporting the massives of the mountains on its foaming back, like a floating load of ugly crags and shale" (Peake, 2011b, $G^{9}$ chap. 15).

4 Hereinafter, the abbreviation TG will refer to Titus Groan, the first novel in the series

Chapter title: 'The Hall of the Bright Carvings.'

Chapter title: 'Sepulchrave.'

Chapter title: 'The Body by the Window.'

Chapter title: 'The Spy-Hole.'

Hereinafter, the abbreviation $\mathrm{G}$ will refer to Gormenghast, the second novel in the series. 
The examples of interconnectedness of the micro- and the macro- planes in the third volume are less conspicuous, they are shorter, and more condensed-they do not permeate the entire story in the volume, and the entire dynamic world of the City, and are mostly limited to its parts, in line with the fragmented nature of the narrative and the characters in the volume. The following example shows how in Titus Alone the perspective can be condensed in a single paragraph to include both a wider view and a focus on a single detail.

Through a gap in the forest the night looked down upon the roofless shell of the Black House studded with fires and jewels. And above the gap, floating away forever from the branches was a small grass-green balloon, lit faintly on its underside. It must have come adrift from its tree-top mooring. Sitting upright on the upper crown of the truant balloon was a rat. It had climbed a tree to investigate the floating craft; and then, courage mounting, it had climbed to the shadowy top of the globe, never thinking that the mooring cord was about to snap. But snap it did, and away it went, this small balloon, away into the wilds of the mind. And all the while the little rat sat there, helpless in its global sovereignty. (Peake, 2011b, $\mathrm{TA}^{10}$ chap. 100)

One of the more elaborate examples is the description of the Lady Cusp-Canine's party as observed by Titus from the roof, which is also one of the most lavish and most beautiful descriptions in the volume. The panorama narrows from the stars "glowing fiercer every moment", to the roofs, and the faces, and "in the irregular gaps between the faces were parts of faces, and halves and quarters at every tilt and angle" (Peake, 2011b, TA chap. 21), and it expands again when Titus, observing the people through the glass on the roof, for a flash, sees something that appears as "a gathering of creatures, of birds, beasts and flowers, as a gathering of humans" (Peake, 2011b, TA chap. 21). The description of people in the room is like a description of a part of the world, an entire ecosystem, given as a range of superimposed faces, body parts, plants, and animals, thus reflecting the presence of the detail in the whole and the whole in the detail.

The connections between the details and the world as a whole, between the micro- and the macro- planes in Titus Alone seem condensed and shorter in length when compared with the stylistically

10 Hereinafter, the abbreviation TA will refer to Titus Alone, the third novel in the series. 
profuse and lavishly detailed descriptions in the first two novels. However, they become more obvious and more revealing of the connections between the two worlds when sought in the elements representative of the two centres, those of Gothic fiction and science fiction, and their overall interconnectedness.

\section{FROM GOTHIC TO SCIENCE FICTION (AND BACK)}

There is a variety of centres that the first two parts of the Gormenghast trilogy encompass, and one of them is that of Gothic fiction, most obvious in the first two volumes, but not exclusive to them. It is also present in the third volume, but not as prominently as the centre of science fiction within which the City seems to fit more comfortably. Unlike the Gothic centre, which is identifiable in both worlds, those of Gormenghast and the City, there are no elements of science fiction in the former. This, however, is in a sense compensated with the presence of anachronic elements that seep into and multiply throughout the story all the way to the "break" that occurs when Titus leaves Gormenghast.

Owing to an ancient feudal family and equally ancient castle, and a notable lack of electricity, sewage, television, radio and other advantages of modern life, Gormenghast initially appears to be a medieval world. However, "Gormenghast is not solely 'medieval' either: there are too many anomalies" (Hindle, 1996, p. 7). Medievalism in Gormenghast quickly, although never entirely, dissolves with the proliferation of the recognizable aspects of modern living such as coffee, sunshades, microbes, a Women's column, tinted glasses, or knowledge of the anatomy of the human body, to name a few. And yet, in absence of its clear position in any known geographical place or period in human history, Gormenghast manages to preserve its medieval aura in the first two volumes.

This medieval aura is largely shaded with typically Gothic tropes. Like Gothic authors who typically gave "full reign to intuition, exuberance, variety, improbability, rough behaviors, and morbid fantasies" (Snodgrass, 2005, p. 153), so did Peake in Gormenghast. The candle-lit corridors and hallways of the castle and their flickering shadows create a Gothic atmosphere that, together with Gothic settings, contributes to a "terror of obscure phantasms and entrapment" with its "collection of sinister paraphernalia, the hidden 
passageways, sliding panels, and trapdoors that allowed villains access to hapless maidens" (Snodgrass, 2005, p. 153).

As Titus followed, the darkness grew more profound with every step and he began to realize that he was moving under the earth, for the roots of trees grew through the roof and the loam of the walls, and the smell of decay was thick in the air.

Had his fear and horror of the silent halls from which he had so recently escaped been less real he would even now have turned about in the constricted space and made his way back to the hollow nightmare from which he had come. For there seemed no end to this black and stifling tunnel. (Peake, 2011b, G. chap. 27)

The tunnel that leads from the castle to the forest is among Gothic paraphernalia that comprise the castle's Gothic shadow, as do the castle's grotesque inhabitants. Steerpike is one of them, a villain who preys on Fuchsia and who gains access to her through the window of her room. By making the castle's walls no obstacle for the movement of the villain who is capable of climbing them up and down, Peake adds the castle's exterior to the list of sinister paraphernalia, commonly internalized in Gothic fiction.

Lord Sepulchrave and his twin sisters are an illustrative example of dissipation and the descent into madness. Some, like the twins, are physically placed in confinement while others, like Titus, feel entrapped and confined, limited, and restrained in Gormenghast. There are numerous examples of doubles, whose roles range from funny and satiric to terrifying. As noted by Winnington, "Peake plays with twinning in his various doubles, producing comedy with Cora and Clarice, and horror with the helmeteers in Titus Alone" (Winnington, 2006, p. 152). The "Professors as a group double for one another as Irma's targets for matrimony" (Mills, 2005, p. 103). The Black House is a twisted, ironic double of Castle Gormenghast. The villain Steerpike can be viewed as Titus's shadowy, ambiguous double. They both drive the plot, one with his inaction and the other through his actions. Both are in search of identity and independence, and while one seeks his freedom in the position he yearns to assume although he is not entitled to it, the other seeks his freedom in trying to evade the position that is rightfully his. Their relationship and tensions between them are resolved with death of one by the hands of the other.

The examples are too numerous to be listed all-from "imperilled heroines, dastardly villains, ineffectual heroes, supernatural 
events, dilapidated buildings and atmospheric weather" (Spooner \& Mc Evoy, 2007, p. 1), which made the first Gothic novels easily identified as such, to madness, dissipation, doppelganger, murder and other recognizable Gothic tropes and themes, Gormenghast offers examples for virtually all of them.

Alice Mills (2005, pp. 68-72) argues against Gormenghast as a Gothic edifice, or a Gothic novel in general.

In its lack of sustained personification, Gormenghast is remarkably free from alignment with Gothic convention. Corridors, rooms and roofs may multiply, and the volume of the buildings may expand, but not for the purpose of embodying a Gothic sense of paranoia. (Mills, 2005, p. 69)

As pointed out, parts of the castle "function at times as sanctuary." "Yet increasingly, sanctuary is lost or defiled" (Mills, 2005, p. 71). Although Gormenghast castle is a medieval(like) structure, in terms of its defiled sanctuary it is more a reflection of Victorian Gothic in which home, once a sanctuary and a place of safety, becomes a place of horror, as in Wuthering Heights, for example, in which, as noted by Warwick, "[i]n contrast to the emphatic Victorian development of the idea of the home as a place of peace, safety and protection, the Brontës' domestic spaces, and the state of marriage or family life that the spaces embody, are terrifyingly ambiguous" (Warwick, 2007, p. 30). There are other examples of homes as places of insecurity and horror in Victorian Gothic fiction. Therefore, although Gormenghast is not a typical Gothic novel, nor should it be treated exclusively as such, the number of Gothic features in it are simply too numerous to be neglected. There is no sustained personification, but the Gothic elements are far from absent, and the sense of paranoia, diluted in the world of Gormenghast, becomes more apparent in the City.

The world of the City in Titus Alone is notably different from that within and around the castle. It is the world of helicopters and airplanes, a world with "a wide stone highway" on which cars flash by "without a sound", a world with "quite a fleet of fish-shaped, needle-shaped, knife-shaped, shark-shaped, splinter-shaped devices, but all kinds of land-machines of curious design", a place with tracing devices "no bigger than a needle" that can thread "a keyhole with the speed of light..." (Peake, 2011b, chap. 15, 18, 63).

The City is an ambiguous space, and a dangerous place, where one of the greatest dangers lurks in the form of misused science and technology. 
Titus is followed by a floating sphere, "filled with glittering wires, an incredible filigree like frost on a pane," a sphere which is "no bigger than the clenched fist of a child, and was composed of some transparent substance, so pellucid that it was only visible in certain lights, so that it seemed to come and go" (Peake, 2011b, TA chap. 46).

At first, Titus had been more amazed than frightened by the mobile globe which had appeared out of nowhere, and followed or seemed to follow every movement he made; but then fear began to make his legs feel weak, for he realized that he was being watched not by the globe itself, for the globe was only an agent, but by some remote informer who was at this very moment receiving messages. (Peake, 2011b, TC chap. 46)

Titus is afraid of it, not because it is a strange object, and unlike anything he has ever seen before, but because it is a means used by a bigger threat. His fear is turned into anger so he smashes it, but then becomes anxious and worried about the consequences of his act. Muzzlehatch explains that these devices can be as "simple as an infant's rattle, or complex as the brain of man" and that the one he smashed "is reputed to be almost human. Not quite, but almost" (Peake, 2011b, chap. 47).

Titus shatters the sphere that is "the very spear-head of advancement" (Peake 2011b, TA chap 47), and Muzzlehatch destroys the factory built by scientists who killed his beloved animals, eliminated without a trace with "some kind of ray" (Peake 2011b, chap. 48). Destructive and inquisitive technology and mass production in Titus Alone are not met with enthusiasm. "We don't want to be watched, do we? Machines are so inquisitive", says Titus to Juno (Peake, 2011b, chap. 42). Titus and Muzzlehatch are forced to act destructively to defend themselves against the technology that makes them angry, threatens them, and hurts them both mentally and physically.

Muzzlehatch warns him about the dangers of the urban world.

Freedom from the swarms of pilotless planes: freedom from bureaucracy: freedom from the police. And freedom of movement. It is largely unexplored. They are ill-equipped. No squadron for the water, sea, or sky. It is as it should be. A region where no one can remember who is in power. But there are forests like the Garden of Eden where you can lie on your belly and write bad verse. (Peake, 2011b, chap. 64) 
The forces that restrict freedom, and threaten, and fuel fears in Titus Alone are scientists and their factories with plumes of smoke that spiral out of their chimneys. The factory is a place that makes "an endless impalpable sound that, had it been translated into a world of odours, might have been likened to the smell of death: a kind of sweet decay" (Peake 2011b, chap. 73). It is a symbol of depersonalization, dangerous for the survival of individuality and the surroundings, a place where, and from where, destructive individuals and technologies lurk.

The factory is a depersonalizing space that threatens to destroy all uniqueness, and everything that is different and authentic. When Titus sees its windows filled with faces staring at him, the most unsettling is the fact that every face is the same. At the sound signal, they all disappear at the same moment. They are the most potent image of control, the image of a bleak future dominated by technology abused by scientists, the future that mocks and suffocates the past and everything that is different, and unique. The controlled, unified faces, when given voice, like the mesmerized audience in the Black House, are only capable of repeating obediently the words that they hear.

The inquisitive sphere is destroyed by Titus and the factory by Muzzlehatch not because they are afraid of technological progress in general, but because they oppose its destructive and depersonalizing potentials. Published in 1959, Titus Alone already considers the topics that were more deeply explored in the 1960's New Wave science fiction, as well as in the postmodernist fiction of the 1960's to 1980 's.

The Under-River is a place devoid of technology, the Gothic underworld and underside of the science fiction world on the surface.

It was always like this in the Under-River, for the days and nights could be so unbearably monotonous: so long: so featureless, that whenever anything really happened, even when it was expected, the darkness appeared to be momentarily pierced, as though by a thought in a dead skull, and the most trivial happening took on prodigious proportions. (Peake, 2011b, chap. 51)

The Under-River is strikingly similar to Gormenghast, as a place, with its atmosphere, and with its dwellers, like a man and his wife, who spends her time "trying to disentangle the knots in the wool", who remembers "days, long ago, when she knew what she was making, and yet earlier days, when she was actually known by the 
clickety-clack of her needles", who are "a part, a tiny part of the Under-River" (Peake, 2011b, chap. 52). The Under-River recalls its timelessness, because like Gormenghast it is "littered with the relics of another age" (Peake, 2011b, TA chap. 47). With its unbearably monotonous days and nights the Under-River recalls its resistance to change. The forgotten purpose of disentangling the wool recalls its rituals with long-lost purpose and meaning. The "dead skull" echoes all the skulls mentioned in the first two volumes, and the "trivial happening" that takes "prodigious proportions" is suggestive of the organic connection between the details and the overall picture, between the parts and the whole, the micro- and the macro- perspectives.

There are other Gothic places and structures in the City. Some, like Titus's cell and the scene in it, when old Crime enters the room through the floor and invites Titus to join his friends, to be an asset, to grow old with them, almost overshadow the weirdness and grotesqueness of Gormenghast.

The most Gothic of all, both as a setting and the effect it produces, is the Black House and the travesty in it organized by Cheeta

It had an atmosphere about it that was unutterably mournful; a quality that could not be wholly accounted for by the fact that the place was mouldering horribly; that the floor was soft with moss; or that the walls were lost in ferns. There was something more than this that gave the Black House its air of deadly darkness; a darkness that owed nothing to the night, and seemed to dye the day. (Peake, 2011b, TA chap. 92)

The Black House is not only a place of horror, it is a place aimed to serve as a means of depersonalization through obliteration of the past. One is no longer a person if one's memories are reduced to mere illusions of a deranged mind. The travesty is meant to convince Titus that Gormenghast does not really exist, that it is only in his mind, and in doing so, to push him over the edge of sanity. If Cheeta managed to do this, to take away Gormenghast from him, everything that he is-his personality, his identity-would also be lost. He would become like the mesmerized audience who, without their own voice, are only capable of repeating what is said, of obediently echoing what they hear.

The passage from the world of Gormenghast Castle to the reality of the City in Titus Alone may seem to make an abrupt switch from, among others, a fuzzy set of Gothic fantasy to an equally fuzzy set of science fiction. But this passage, this shift, should not come as a 
surprise because it is actually openly and directly announced at the end of the second volume.

The world that he pictured beyond the secret skyline-the world of nowhere and everywhere was necessarily based upon Gormenghast. But he knew that there would be a difference; and that there could be no other place exactly like his home. It was this difference that he longed for. There would be other rivers; and other mountains; other forests and other skies. (Peake, 2011b, G chap. 80)

The City is different from Gormenghast because "there could be no other place exactly like his home." The dynamic, urban City, closer and more similar to the contemporary world of the reader than the timewise and spacewise ambiguous domain of Gormenghast, is more a science fiction story than fantasy. Although they are often called the "Gormenghast trilogy" Winnington noticed that it would be more accurate to call them "the Titus books" since they are about the hero; however, "it's the place rather than the plot that remains in the mind" (Winnington, 2006, p. 5). Marked by the absence of definite dimensions and uniform architectural style, Gormenghast Castle is a place where the real overlaps with the imaginary, fantasy, and dreams. The overall picture of the castle and the world it encompasses gradually becomes clearer, but never entirely clear. One question that can be asked is: Is there Gormenghast as a place at all other than in the mind?

At the very beginning of the third volume, Titus leaves Gormenghast behind as "something half real: something half dream; half of his heart; half of himself" (Peake, 2011b, TA chap. 1). The shift from one world to another is not meant to leave Gormenghast forever behind, but to create, or reveal, yet another piece of the puzzle that it is.

Brian McHale's observation that epistemologically-oriented fiction is preoccupied with the questions about what is there to know about the world, who knows it and how reliably, whereas ontologically oriented fiction, like science fiction and postmodernism is preoccupied with questions such as

What is a world? How is a world constituted? Are there alternative worlds, and if so, how they are constituted? How do different worlds, and different kinds of world, differ, and what happens when one passes from one world to another? (McHale, 1992, p. 247)

can help explain the nature and purpose of the passage into a different world in Titus Alone. With Titus's passage one of the centres 
of Gormenghast shifts from Gothic to science fiction, and with it comes a shift from the epistemological to ontological dominant. Titus Alone, in that sense, asks numerous questions about the two worlds.

Were they coeval; were they simultaneous? These worlds; these realms-could they both be true? Were there no bridges? Was there no common land? Did the same sun shine upon them? Had they the constellations of the night in common?

When the storm came down upon these crystal structures, and the sky was black with rain, what of Gormenghast? Was Gormenghast dry? And when the thunder growled in his ancient home was there never any echo hereabouts?

What of the rivers? Were they separate? Was there no tributary, even, to feel its way into another world? (Peake, 2011b, TA chap. 18)

The two realms, the one of Gormenghast and the one of the City, are more a continuum than a world broken into pieces that are set apart. The transition to the City is not a radical break, but a change in the dominant, from the epistemological to the ontological, from questions about the nature of the world of Gormenghast that are foregrounded in the first two volumes of the story, to questions about the nature and relations between the two worlds, Gormenghast and the City, which are foregrounded in the third volume.

CONCLUSION Although the futuristic, urban world of the City is markedly different from the world of the first two novels that form an anomalous unity maintained and preserved with its ancient castle, its eponymous dynasty, its meaningless rituals, and its pseudo-medievalism, Titus Alone further elaborates the anomaly of Gormenghast but it keeps it within the perimeter of the story.

Gormenghast is not a Gothic novel, at least not only Gothic, and its third volume is not only science fiction, but if the passage to the City is viewed from the perspective of a shift from the Gothic centre to a science fiction one it becomes easier to regard Titus Alone as a continuation of the story rather than a radical break that sets the two worlds apart.

Titus Alone can be viewed as a novel that brings about a shift to science fiction tropes and postmodernist strategies. It represents a new stage of Peake's artistic development that can even be regarded as one that announced the ontologically-oriented tendences in 
literature much earlier than some other works of fiction often mentioned in this context.

The Gothic and the science fiction centres are not, nor should they be, regarded as dominant over the other variety of sets that Gormenghast encompasses, but the focus on them may help explain why and how the three novels together make an anomalous, yet uniquely recognizable world. Bringing other centres into the spotlight may bring about new insights about the great, anomalous, fuzzy set of Gormenghast.

REFERENCES Aldiss, B. W. (1973). Billion Year Spree: The True History of Science Fiction. New York: Doubleday and Company.

Attebery, B. (2004). Fantasy as Mode, Genre, Formula. In: D. Sandner (Ed.), Fantastic Literature: A Critical Reader (293-309). Westport, Connecticut, London: Praeger.

Binns, R. 1979. Situating Gormenghast. Critical Quarterly 21 (1), 21-33.

Gardiner-Scott, T. (1988). Mervyn Peake: The Relativity of Perception.Journal of the Fantastic in the Arts 1 (2), 13-24.

Gardiner-Scott, T. (1989). Through the Maze: Textual Problems in Mervyn Peake's Titus Alone. Extrapolation 30 (1), 70-83.

Hindle, R. (1996). Elysian Fields, Hadean Glooms: Titus Groan's Mythical Quest. Peake Studies 4 (4), 7-20.

Manlove, C. (2013). Shaping in Titus Groan. In: G. Peter Winnington (Ed.), Miracle Enough-Papers on the Works of Mervyn Peake (21-32). Newcastle upon Tyne: Cambridge Scholars Publishing.

McHale, B. (1992). Constructing Postmodernism. London, New York: Routledge.

Mendlesohn, F. (2013). Peake and the Fuzzy Set of Fantasy: Some Informal Thoughts. In: G. Peter Winnington Ed.), Miracle Enough: Papers on the Works of Mervyn Peake (61-74). Newcastle upon Tyne: Cambridge Scholars Publishing.

Mills, A. (2005). Stuckness in the Fiction of Mervyn Peake. Amsterdam-New York: Rodopi.

Mills, A. (2002). Inspiration and Astonishment: Peake's Influence on Perdido Street Station. Peake Studies 7 (4), 19-24.

Peake, M. (2011a). The Artist's World. Peake Studies 12 (2), 5-9.

Peake, M. (2011b). The Illustrated Gormenghast Trilogy. London: Vintage Books. Kindle.

Redpath, P. (1989). Mervyn Peake's Black House: An Allegory of Mind and Body. Ariel 20 (1), 57-74. 
Snodgrass, M. E. (2005). Encyclopedia of Gothic Literature. New York: Facts on File, Inc.

Spooner, C. and McEvoy, E. (2007). The Routledge Companion to Gothic Fiction. London and New York: Routledge.

Warwick, A. (2007). Victorian Gothic. In: Catherine Spooner and Emma McEvoy (eds.), The Routledge Companion to Gothic Fiction (29-37). London and New York: Routledge.

Winnington, G. P. (2006). The Voice of the Heart: The working of Mervyn Peake's Imagination. Liverpool: Liverpool University Press.

Winnington, G. P. (2013). Peake and Alice (and Arrietty). In: G. Peter Winnington (Ed.), Miracle Enough-Papers on the Works of Mervyn Peake (1-19). Newcastle upon Tyne: Cambridge Scholars Publishing.

МЛАДЕН М. ЈАКОВЉЕВИЋ

УНИВЕРЗИТЕТ У ПРИШТИНИ СА ПРИВРЕМЕНИМ СЕДИШТЕМ

У КОСОВСКОЈ МИТРОВИЦИ, ФИЛОЗОФСКИ ФАКУЛТЕТ

КАТЕДРА ЗА ЕНГЛЕСКИ ЈЕЗИК И КЬИЖЕВНОСТ

РЕЗИМЕ

ПУТОВАЊЕ ТИТУСА ГРОУНА: ОД ГОРМЕНГАСТА ДО ГРАДА

Прелаз протагонисте Титуса Гроуна из псеудосредњовековног

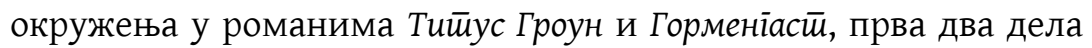
трилогије Горменгаст Мервина Пика, у футуристички свет града у трећем делу насловљеном Усамљени Тийус, често се посматра као радикални прелаз из једног света у други. Овај неочекивани искорак у нови урбани свет доноси једнако неочекивани прелаз у научнофантастични контекст. Оठе ове промене, прелаз у други, другачији свет и прелаз у жанр научне фантастике, нису толико нагле, неочекиване и радикалне колико се то иницијално може чинити.

Фокусирање на готске и научнофантастичне жанровске особености трилогије (при чему се не поричу и не умањују присуство и значај других жанрова у делу), појашњава како је стварност у трилогији обликована, како су њена два света повезана у целину и како се та два света узајамно обликују креирајући свеукупну слику, пејзаж и реалност Горменгаста. Скупа, готски и научнофантастични тропи додатно расветљавају кључне елементе ове Пикове необичне приповести. 
Кључне РЕчи: Мервин Пик; Горменгаст; научна фантастика; готска проза; фантазијска књижевност.

Овај чланак је објављен и дистрибуира се под лиценцом Creative Commons Ауторство-Некомерцијално Међународна 4.0 (CC BY-NC 4.0 |

https://creativecommons.org/licenses/by-nc/4.0/).

This paper is published and distributed under the terms and conditions of the Creative Commons Attribution-NonCommercial International 4.0 licence (CC BY-NC 4.0 | https://creativecommons.org/licenses/by-nc/4.0/). 